\title{
Osler ne ferait pas recette aujourd'hui
}

\section{Werner Bauer}

Dr méd., président de I'Institut suisse pour la formation médicale postgraduée et continue (ISFM)

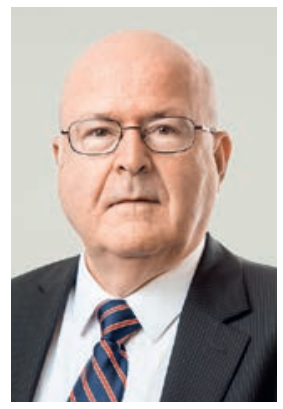

Un article [1] intitulé «Sir William Osler: Would He Have Made His Relative Value Units (RVUs)?» est récemment paru dans les Annals of Internal Medicine. Il m’a impressionné parce qu'il montre à quel point la pondération des différents enjeux de notre activité de médecins a changé au cours des dernières décennies. Osler était un médecin légendaire. Né au Canada en 1849, il est décédé en Angleterre en 1919. Son parcours professionnel débute par sa formation et son premier emploi à l'Université McGill de Montréal, suivis d'une chaire de médecine clinique à l'Université de Pennsylvanie à Philadelphie, de la direction du département de médecine interne de l'Hôpital Johns Hopkins de Baltimore qui venait d'ouvrir et enfin de la «Regius Professorship of Medicine» à Oxford, créée en 1546 par le roi Henry VIII. Il est unanimement décrit comme un médecin exceptionnel et attentif, un enseignant engagé, encourageant ses élèves et un scientifique passionné. Il est l'auteur du manuel Principles and Practice of Medicine, réédité quinze fois, et de nombreuses citations qui nous sont parvenues [2] et dont les idées fondamentales restent étonnamment actuelles, comme sa définition concise et pertinente de la médecine: «Medicine is a science of uncertainty and an art of probability.» Sa foi dans l'importance de l'enseignement mérite aussi d'être rappelée: "The work of an institution in which there is no teaching is rarely first class. It is, I think, safe to say, that in a hospital with students in the wards the patients are more carefully looked after, their diseases are more fully studied and fewer mistakes made."

L'auteur a étudié les conditions et les méthodes de travail de William Osler à ses différents postes en se basant sur les «relative value units (RVUs)», aujourd'hui utilisées aux Etats-Unis pour saisir la productivité des médecins en vue de calculer leur rémunération. A l'image de notre système de points tarifaires, elles reposent sur trois composantes: "physician work", «practice expense» et «malpractice expense» (!). Howard Weitz s'est d'abord mis en quête de documents administratifs au sujet du poste de Philadelphie, mais n'a rien trouvé: «I could not find a job description, contract or any other documentation that the university could have used to benchmark Osler's productivity. Either this documentation has been lost or its absence is an example of how different our era is from Osler's.» Les biographies d'Osler ont en revanche fourni de plus amples informations sur son quotidien professionnel: il passait l'essentiel de ses matinées dans deux grands services de l'hôpital universitaire, qu'il quittait fréquemment l'après-midi «by the back entrance» pour se rendre à l'«Old Blockley», l'hôpital des pauvres de Philadelphie, où il examinait soigneusement les patients, enseignait et réalisait aussi des autopsies (non facturables). Il n'accordait que des consultations limitées, collégiales, pour lesquelles il n'a émis que deux factures entre février et mai 1885, par exemple. Il était par contre très actif au sein des sociétés médicales, en tant qu'éditeur de revues et que professeur de médecine. L'auteur de l'article n'a pas besoin de se perdre en calculs et en estimations pour conclure qu'Osler n'aurait jamais obtenu les RVU aujourd'hui exigées du CEO d'un hôpital. Lorsqu'il a quitté Philadelphie pour Baltimore, l'hôpital s'est interrogé avec des accents de désespoir: «We are about to lose Osler, and what in the world shall we do?» Les considérations financières ne jouaient aucun rôle dans ce désarroi. H. Weitz a écrit un article original qui ne permet bien sûr pas de remonter le temps, mais qui remet en question la valeur que l'on accorde de nos jours aux performances et à la productivité. Sa conclusion: «Now, 100 years since Sir William died, it is time we step back and refocus on what the real values of the master clinician-educator should be: teaching, mentoring, collegiality, research, and care of the patient. If not, I fear that someone a century from now will look back on our era and ask, 'Why did they allow it to happen?'."

\section{Références}

1 Weitz HH. Sir William Osler: Would he have made his relative value units (RVUs)? Ann Intern Med. 2019;171:208-9.

2 Silvermann ME, Murray TJ, Bryan CS (editors). The quotable Osler. American College of Physicians. 2008. 